\title{
Fatima Chahin-Dörflinger (Germany) Reflection and Evaluation of Distance Education in School
}

\begin{abstract}
When schools in Germany were closed in Spring 2020 due to the COVID-19 pandemic, distance teaching and learning was implemented. Teachers and schools strived to recreate learning programs and education in a new and unknown way. To learn about ways that distance learning can work well for students and schools, several teachers and principals started to evaluate their distance teaching and learning with scientific support of the evaluation service center of the Institute of Educational Analysis (IBBW). The findings of this action research led to a model of orientation for reflection and development of digital distance teaching and learning in schools.
\end{abstract}

Keywords: distance education; digital learning; self-evaluation; reflexion; quality development

摘要 (法蒂玛 查欣-德弗林格: 学校远程授课的反思与评估)：由于新冠状病毒的大流行，当德国的学校于 2020 年春季关闭时, 实施了远程教学。老师和学校努力以一种新的及未知的方式重新创建学习计划和教 育。为了解远程学习可以为学生和学校发挥良好作用的方式方法, 几位老师和校长在教育分析研究所( $I B B W ＼mathrm{~ ） 评 估 服 务 中 心 的 科 学 支 持 下 开 始 评 估 他 们 的 远 程 教 学 。 这 项 行 动 研 究 的 结 果 导 致 了 一 种 为 了 反 思 ~}$ 及发展在校数字远程教学的导向模型。

关键词: 远程教育; 数字化学习; 自我评估; 反思; 质量发展

$* * *$

摘要 (法蒂瑪 查欣-德弗林格: 學校遠程授課的反思與評估)：由於新冠狀病毒的大流行，當德國的學校於 2020 年春季關閉時，實施了遠程教學。老師和學校努力以一種新的及未知的力式重新創建學習計劃和教 育。為了解遠程學習可以為學生和學校發揮良好作用的方式方法, 幾位老師和校長在教育分析研究所( $I B B W ）$ 評估服務中心的科學支持下開始評估他們的遠程教學。這項行動研究的結果導致了一種為了反思 及發展在校數字遠程教學的導向模型。

關鍵詞：遠程教育；數字化學習；自我評估; 反思; 質量發展

Zusammenfassung (Fatima Chahin-Dörflinger: Reflexion und Bewertung des Fernunterrichts in der Schule): Als im Frühjahr 2020 die Schulen in Deutschland aufgrund der COVID-19-Pandemie geschlossen wurden, wurde der Fernunterricht und -unterricht eingeführt. Lehrer und Schulen strebten danach, Lernprogramme und Bildung auf eine neue und unbekannte Art und Weise neu zu gestalten. Um zu erfahren, wie der Fernunterricht für Schüler und Schulen gut funktionieren kann, begannen mehrere Lehrer und Schulleiter mit wissenschaftlicher Unterstützung des Evaluationsservicezentrums des Instituts für Bildungsanalyse (IBBW), ihren Fernunterricht und ihr Fernstudium zu evaluieren. Die Ergebnisse dieser Aktionsforschung führten zu einem Orientierungsmodell für die Reflexion und Entwicklung des digitalen Fernunterrichts und -lernens in Schulen.

Schlüsselwörter: Fernunterricht; digitales Lernen; Selbstevaluation; Reflexion; Qualitätsentwicklung

Резюме (Фатима Чахин-Дерфлингер: Рефлексия и оценка дистанционного обучения в школе): Когда весной 2020 года все школы Германии вынуждены были закрыться из-за пандемии COVID-19, начался повсеместный переход на дистанционное обучение. Школы оказались перед необходимостью вести обучение в новом формате, с помощью методов, которые ранее активно не применялись. Для того чтобы осуществлять мониторинг того, насколько эффективным является новый формат для учеников, учителя и директора школ начали системную эвалюацию данного процесса при научной поддержке специализированного центра при Институте анализа качества образования. Результаты этих исследований были положены в основу создания ориентационной модели, $c$ помощью которой можно оценивать и определять перспективы использования дистанционного формата в школьной практике.

Ключевые слова: дистанционное обучение, обучение с помощью информационных технологий, самоэвалюация, рефлексия, совершенствование качества 


\section{Introduction}

Effective school improvement planning is a continuous process of considering what is working well and what needs to improve. This is done also in a more informal way on an individual level by teachers who reflect on their teaching. Systematic evaluation of teaching and learning is required as well by educational policies and by the standards of the Kultusministerkonferenz (conference of the ministers of education of the German States; KMK) in Germany (KMK, 2019). What is meant by effective and good education in school? The actual goal of providing schooling is not only to teach skills and transfer knowledge to students in the classroom. The focus shifts to a more holistic view on school considering equity, excellence, and well-being of learners (UNESCO, 2016; Sliwka, 2018).

Almost overnight, teachers, students, principals, parents and the school administration had to ensure school education without the formal school settings. The complete closure of schools made usual activities, measures and processes no longer practicable. Social distance measures made it difficult to monitor the learning processes and efforts of students. It was obvious that not all of the students were reached by the remotely assigned tasks and learning programs. Teaching became a new challenge for many teachers who were not sufficiently trained to teach in a distance learning environment. School adminstrators were occupied with organizing the implementation of regulations to prevent the spread of infection.

In this complex situation, some teachers adressed the service center for evaluation at the Institute of Educational Analysis (IBBW) for advice and scientific support. They wanted to find out what aspects are essential for excellence in new learning scenarios. We started to analyze the general setting in teaching and learning and researched the fundamentals and concepts behind the changing conditions. What are the common and unchanging goals of education? Which proven scientific theories and models are available and are coherent with school standards and appropriate to the knowledge base of teachers and practioners? How can the special conditions of the school including staff, students, parents, and school environment be taken into account? The collaborative interaction between scientific approach and practical view helped the teachers develop and carry out evaluations tailored to their own needs. On one hand, the results were the basis for decisions and actions at schools. On the other hand, the findings led to a framework for school quality and further monitoring of digital distance schooling.

The methodology, the concepts and the results and findings will be presented in the following sections of this article.

\section{Methodology}

Action research is a cooperative endeavour between such practitioners as teachers or principals working with a scientist or researcher in a sustainable relationship. It is used in settings "where a problem involving people, tasks, and procedures cries out for solution, or where some change of feature results in a more desirable outcome" (Cohen et al., 2011:344). According to Kemmis and McTaggart (1988), action research is a form of collective reflective enquiry by participants in order to improve their (educational) practices, as well as their understanding of practices, methods, concepts (Cohen et al., 2011:345). The outcomes for both practitioner and researcher are the insights they can apply to their workplace and field of study. This method seemed suitable to jointly clear up unexplored areas of educational science and unfamiliar fields of action in school that arose as the result of the COVID-19 pandemic. Relying on the work of Sagor 2005 (Cohen et al., 2011:353), a stage model of action research was used to evaluate distance schooling. In stage 1 , vision and targets were clarified; this was mainly driven by the interests of the teachers and their experiences. For the articulation of appropriate theories in stage 2, scientific research was examined, and concepts and theories were enlightened and discussed. In stage 3 , the evaluation took place, and group ideas and practical solutions were developed. The teachers brought in ideas that addressed real situations in their schools, and the researcher facilitated valid and useful empirical data collection. Reflection on the data and informed action informed both improvements at the schools and a contribution to empirical scientific knowledge about digital and distance learning. 


\section{Concepts and Models of Digital Learning and Schooling Quality}

In the discussion of targets, goals, and purpose of the evaluation that the teachers or principals wanted to develop, scientific models and concepts helped to identify critical aspects to examine and to enlarge and deepen the knowledge about digital learning and schooling quality.

\subsection{Digital Learning}

Puentedura's Substitution, Augmentation, Modification, and Redefinition (SAMR) model was developed to reflect the transfer from analog to digital task formats. Puentedura (www.hipassus.com) is of the opinion that digital media should not be used as a substitute for the analog way of working (e.g. the pure provision of worksheets as PDFs); rather he encourages teachers to use the new possibilities of digital media for modern teaching. Schools can use the SAMR model as a common language to enable meaningful learning experiences with digital media. It invites teachers to reflect on the way in which they integrate digital media into their lessons: as a direct replacement for work equipment without functional change, as an extension, change or renewal by designing new tasks that were previously unimaginable. Although Kimmons et al. (2020) argue that the level boundaries in the SAMR model are unclear, the alignment and coherence with other official publications for schools and the slower aproach in digital improvement were reasons to keep the older model as the basis for reflection.

The TPACK model (Mishra, \& Koehler, 2006) is based on the work of Shulman (1986) and represents the types of knowledge that form the basis of competencies of teachers. This model distinguishes between content-related knowledge (subject-specific), pedagogical knowledge, and technological knowledge. The model-typical overlapping the three areas (see figure) is called TPACK knowledge, whereby this synthesis produces more than just the sum of its individual parts (Mishra, \& Koehler, 2006).

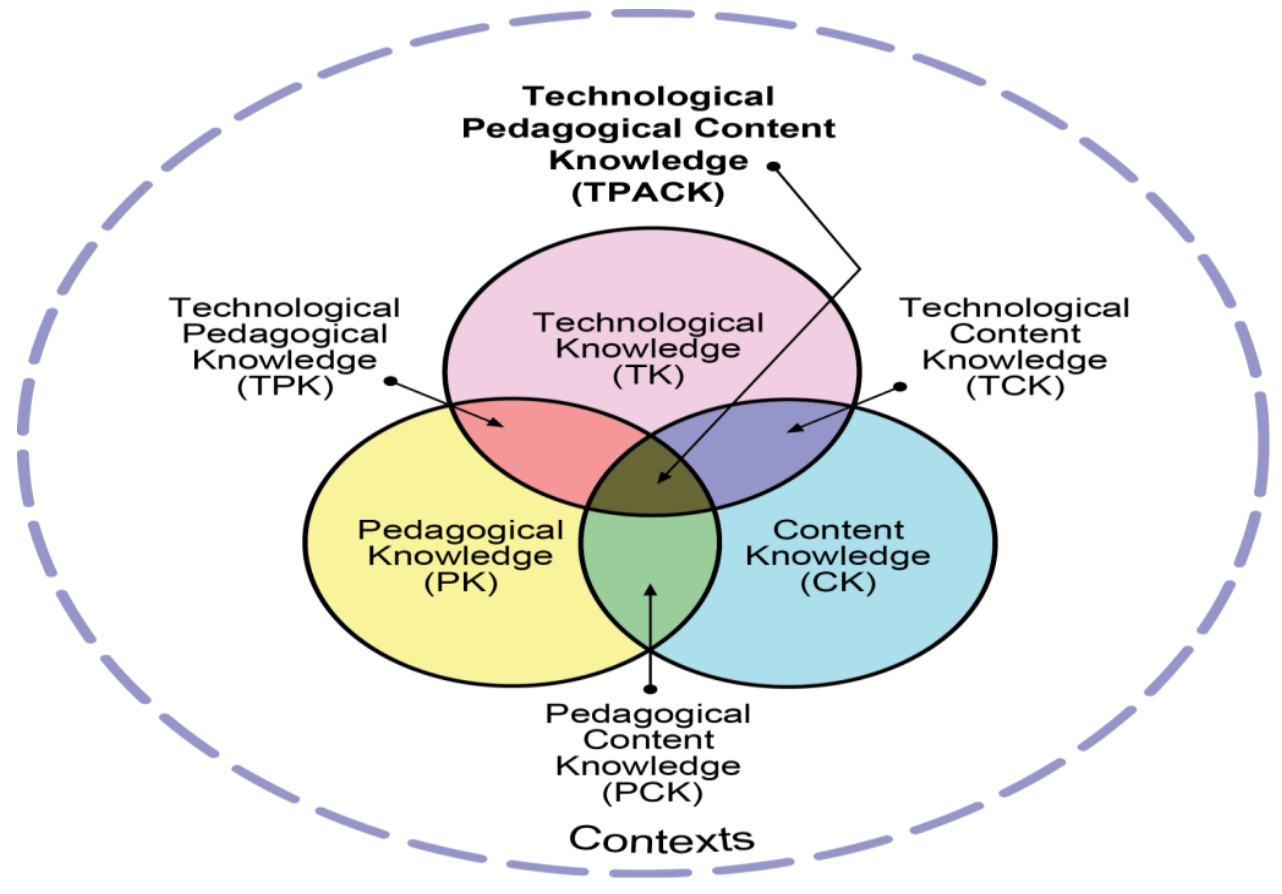

Figure 1: TPACK-Model from www.puyamishra.com

TPACK reflects the idea that every teaching activity or task requires an integration of the surrounding TPACK knowledge area in order to create the best possible fit. The forms of knowledge are embedded in a teaching context as institutional and personal conditions, which also have an influence on the teaching 
situation and the learning process. The model makes it clear that TPACK knowledge must always be newly adapted to every situation or task, and, specifies fields in which teachers can undertake further training.

\subsection{Schooling Quality and School Development}

The paradigm of quality development in the educational system in Germany since the 1990s has focused on the development of individual schools. School development is presented according to Rolff (2013:20) as a system consisting of organizational development, teaching development and personnel development. Taking into account the perspective that information technology is indispensable in schools today, this model is expanded to include a further field: technical development. The focus is not only on teaching and learning, but also on organizational processes, ICT improvement, the role of the school management, and the cooperation and professional competencies of the teachers, as important for a successful school.

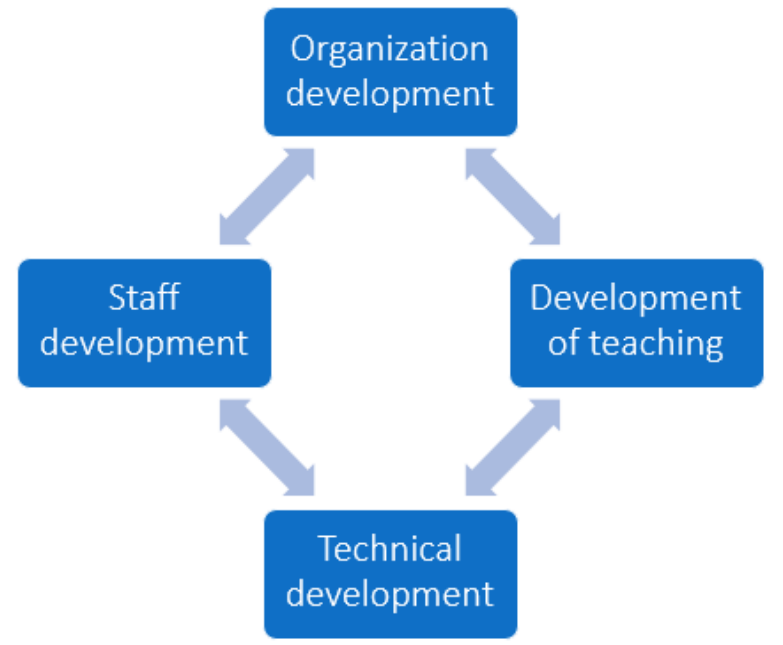

Figure 2: Adapted from Rolff (2013)

Quality teaching occurs when the teacher knows how to apply classroom management, offers a challenging, motivating, and appropriate learning program, undertakes ongoing analysis of the learning process of students, and offers support when necessary (Kunter \& Trautwein 2013). Numerous studies on the effectiveness of teaching have confirmed the importance of deep structures in contrast to visual structures (Trautwein, Sliwka, \& Dehmel, 2019).

The $4 \mathrm{~K}$ model of learning is not about technology, but about competencies that are of particular importance in the 21st century: communication, collaboration, creativity, and critical thinking. These should be acquired and promoted in school, whereby digital media and ICT can be helpful.

\section{Action Research and Findings}

The teachers who were involved in the evaluation project came from different school types: 1 elementary school, 1 secondary school (Gemeinschaftsschule), 1 high school (Gymnasium), 2 vocational schools. The evaluation activities took place in the time period between April 2020 (three weeks after the school closure and before the Easter holiday break) and June 2020. The themes, which were chosen for evaluation during distance schooling were:

- Technical tools and their usability (video conference software, learning platforms, messenger);

- Availability of digital tools to find out who needs support or tools;

- Individual learning needs of students;

- Continuity of learning and drop-out rate of lost students; 
- Feedback and formative assessment of student learning;

- Communication and contact with the students;

- Differentiation for individual or personalized learning;

- Self-estimated ICT-competencies;

- Engagement and support of parents

The results of the evaluation were used at the schools for schooling decisions, improvement activities and to provide an overview about ICT competencies, activities, and attitudes of the staff.

Considering the selected models and concepts for digital teaching and learning and school quality, possible themes for monitoring, evaluation, and improvement are shown in the following mind map. The framework will be used to develop future internal evaluation projects in schools and for the development of surveys by outside partners.

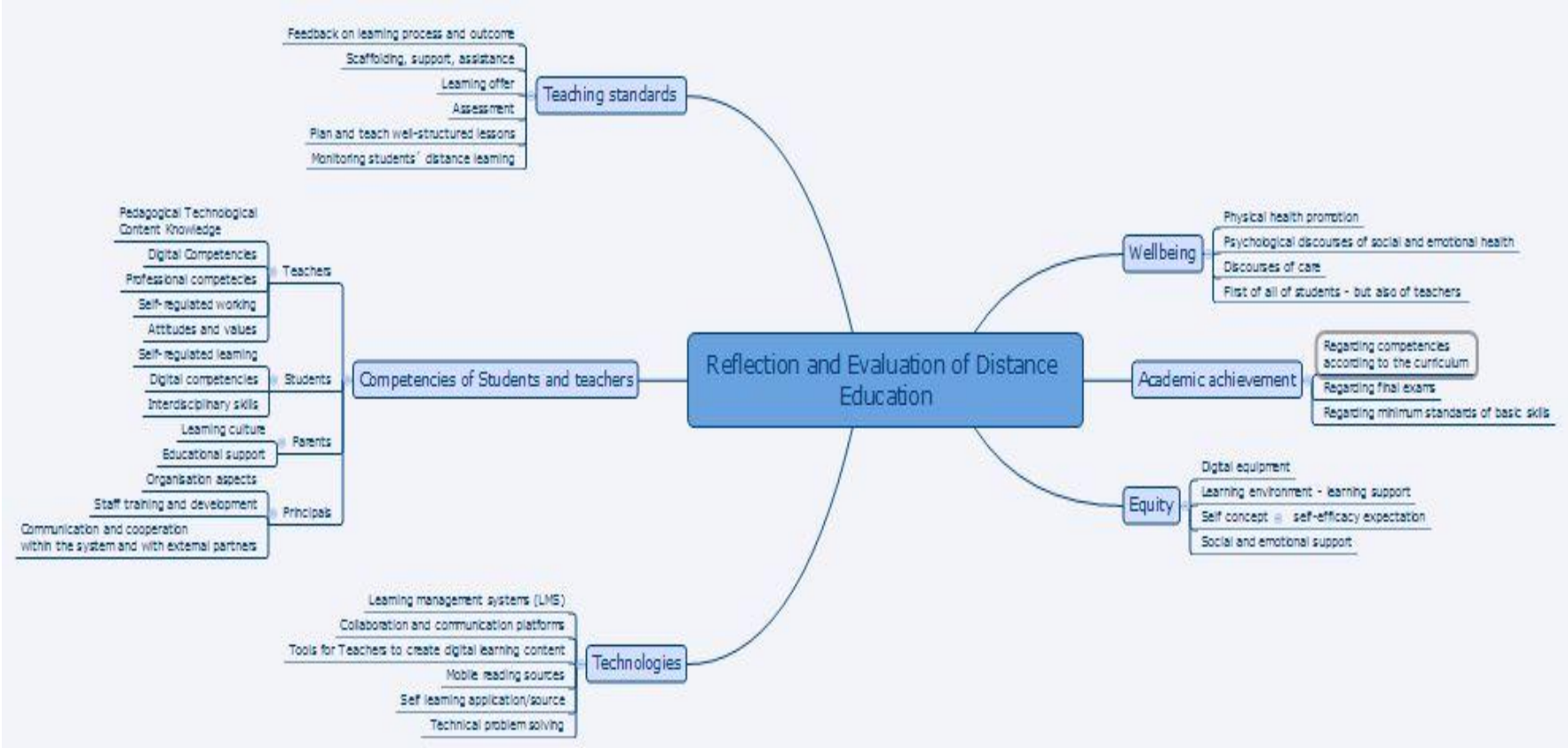

Figure 3: Overview about possible evaluation focus

\section{Conclusion}

The Covid-19 pandemic challenge offers the opportunity to say goodbye to outdated patterns of school design (also with regard to their empirical learning effectiveness) and to consider the experiences during the pandemic as an opportunity for sustainable innovation.

This transformation process will only succeed if it assumes a holistic quality. In digital, hybrid, or distance schooling, teachers have to experiment, to create new teaching and learning settings, to provide formative feedback to the learning process, and communicate and interact with pupils and parents as partners with the aim of improving teaching and opening up lifelong learning as competencies for the future. Monitoring and evaluation as an engine for goal- and evidence-based development and improvement is required.

\section{References}

Cohen, L., Manion, L., \& Morrison, K. (2011). Research methods in education. $7^{\text {th }}$ edition. Milton Park: Routledge 
Kimmons, R., Graham, C. R., \& West, R. E. (2020). The PICRAT model for technology integration in teacher preparation. In Contemporary Issues in Technology and Teacher Education, 20(1), pp. 176-198.

KMK 2019. Standards für die Lehrerbildung: Bildungswissenschaften (Beschluss der Kultusministerkonferenz vom 16.12.2004 i. d. F. Vom 16.05.2019). URL. https://www.kmk.org/fileadmin/Dateien/veroeffentlichungen beschluesse/2004/2004_12 16-Standards-Lehrerbildung-Bildungswissenschaften.pdf (retrieved 2020, June 10).

Kunter, M., \& Trautwein, U. (2013). Psychologie des Unterrichts. Stuttgart: UTB

Mishra, P., \& Koehler, M. (2006). Technological Pedagogical Content Knowledge: A Framework for Teacher Knowledge. In Teachers College Record Volume 108, Number 6, June 2006, New York: Columbia University, pp. 1017-1054.

Rolff, H. (2013). Schulentwicklung kompakt. Modelle, Instrumente, Perspektiven. Weinheim: Beltz

Sliwka, A. (2018). Lernwirksamer Unterricht: Empirische Forschung und internationale Entwicklungen in besonders leistungsstarken Schulsystemen. Presentation during a conference, hold at the State Institute of Educational Development Stuttgart on 2018, June 15 $5^{\text {th }}$.

Trautwein, U., Sliwka, A., \& Dehmel, A. (2019). Grundlagen für einen wirksamen Unterricht. Wirksamer Unterricht - Band 1. Stuttgart: Landesinstitut für Schulentwicklung (LS). URL. https://ibbw.kultusbw.de/site/pbs-bw-new/get/documents/KULTUS.Dachmandant/KULTUS/Dienststellen/ibbw/Empirische\%20Bildungsfor-schung/Programme-und-Projekte/Wirksamer Unterricht/Wirksamer\%20Unterricht\%20-\%20Band\%201 Trautwein\%20et\%20al.\%20\%282018\%29 Grundlagen.pdf (retrieved 2020, June 10).

UNESCO (2016). Education 2030: Incheon Declaration and Framework for Action for the implementation of Sustainable Development Goal 4: Ensure inclusive and equitable quality education and promote lifelong learning opportunities for all. URL: https://unesdoc.unesco.org/ark:/48223/pf0000245656 (retrieved: 2020, August 20)

\section{About the Author}

Fatima Chahin-Dörflinger: Institute of Educational Analysis, Stuttgart \& University of Education, Freiburg (Germany); e-mail: fatima.chahindoerflinger@ph-freiburg.de 